\title{
Majority and Minority Nationalism in the Danish Post-Welfare State
}

\author{
Koefoed, Lasse Martin
}

Published in:

Geografiska Annaler. Series B. Human Geography

DOI:

10.1111/geob.12077

Publication date:

2015

Document Version

Early version, also known as pre-print

Citation for published version (APA):

Koefoed, L. M. (2015). Majority and Minority Nationalism in the Danish Post-Welfare State. Geografiska Annaler. Series B. Human Geography, 97(3), 223-232. https://doi.org/10.1111/geob.12077

\section{General rights}

Copyright and moral rights for the publications made accessible in the public portal are retained by the authors and/or other copyright owners and it is a condition of accessing publications that users recognise and abide by the legal requirements associated with these rights.

- Users may download and print one copy of any publication from the public portal for the purpose of private study or research.

- You may not further distribute the material or use it for any profit-making activity or commercial gain.

- You may freely distribute the URL identifying the publication in the public portal.

\section{Take down policy}

If you believe that this document breaches copyright please contact rucforsk@kb.dk providing details, and we will remove access to the work immediately and investigate your claim. 
MANUSCRIPT ID: 201309-8

Majority and Minority Nationalism in the Danish Post-Welfare State

Lasse Koefoed

Department of Environmental, Social and Spatial Change

Roskilde University

Postboks 260

4000 Roskilde

Denmark

E-mail: Lmartin@ruc.dk 


\title{
MAJORITY AND MINORITY NATIONALISM IN \\ THE DANISH POST-WELFARE STATE
}

by

\author{
Lasse Koefoed
}

KOEFOED, L. (2015): 'Majority and minority nationalism in the Danish post-welfare state', Geografiska Annaler: Series B, Human Geography 97 (3): ........

\begin{abstract}
The future of the nation and the Danish welfare state is one of the most important political issues today. The transition in neoliberal governance from welfare state to security state, the ongoing securitization of global and European mobility, the restructuring of public services and the re-scaling of political and economic power has made the debate around the welfare state central. In this article I take an approach to the welfare nation state that is based in the practices and narratives of everyday life. The argument is that narrative practices in everyday life constitute a central sphere inviting studies of the struggle over the welfare community and meaning. The empirical material draws on two recent research projects that include narratives and perspectives from minority and majority population in Denmark. By analysing different perspectives on the nation the article intends to open up for both shared narratives on the welfare state but also differences in the ongoing struggle over the right to the nation.
\end{abstract}

Keywords: nationalism, nation, minorities, everyday life, welfare state 


\section{Introduction}

Who has the right to the nation? In a Danish context this questions is central in the struggle over the future of the welfare state and community. Situated in a "peaceful" corner of the world the image of Denmark is usually one of the well established and relatively homogenous nation state while nationalism is viewed as something far removed and distant in time and space. Denmark has historically regarded itself as a tolerant country that place high value on solidarity, equality and social cohesion created through a well developed welfare system. This image is challenged by the transition in neoliberal governance from welfare state to security state - global and European mobility, the restructuring of public services and the re-scaling of political and economic power and has made discussions about who belongs and who does not belong to the nation central. Especially minorities have been stigmatized in the ongoing discussion on the future of the nation and the welfare community related to the growth in national populism, xenophobia and racism in Denmark (Wren 2001; Brun and Hersh 2008; Hervik 2012).

As a part of a special issue on Neoliberalism and post-welfare Nordic States in Transition this article intend to demonstrate how a new configuration of a differentiated banal nationalism based on everyday practices and narrative perspectives can be understood. First, the attempt is to illustrate by empirical examples that the Danish welfare state has developed from a meanings full category in everyday life related to social security and solidarity into a narrative about the threatening "other". Processes of neoliberalism do not only mean a reconstruction and transformation of the state, it has at the same time been followed by a (in)visible incorporation of orientalist discourses and stereotypes. This is obvious in the way restrictions on migration and issues of integration have been of highest priority in Danish politics since 2001 where antiimmigration politics has become mainstream and routine throughout nearly the entire political spectrum in Denmark (Ersbøl 2010). The aim of the article is therefore first, to address the process of post welfare in relation orientalism and neoliberalism from the perspective of everyday nationalism. Secondly, the aim is to identify counter discourses and minority perspectives on Danishness.

The theoretical framework in this article is based on the concept of banal nationalism (Billig 1995). While some of the main theories on nation and nationalism often have emphasis on historical and more structural analysis (e.g. Hobsbawm 1990 and Gellner 1983) banal nationalism addresses how the nation is practised and how it is part of everyday life stories and identity of belonging. The argument is that narrative practices in everyday life constitute a central sphere 
inviting studies of the struggle over the welfare community and meaning. By comparing minority and majority perspectives on the nation the article intends to open up for both shared narratives but also differences and struggles related to the position of being either minority or majority respectively.

The article draws on two different research projects: Globalisation and negotiation of Danish identity (Koefoed 2006) and The stranger the city and the nation (Koefoed and Simonsen 2010). Opposite the two previous research projects and related publications this article compare majority and minority perspectives on the nation respectively. The first project was carried out as a case study with fieldwork conducted in Hundested, a medium-size town in northern Zealand situated $65 \mathrm{~km}$ from Copenhagen. It is based on qualitative in-depth interviews collecting narrative on national identity by respondents representing majority nationalism in Denmark. The second research project consists of empirical material that comes from in-depth interviews with Copenhagen residents having a Pakistani background. The group consists of immigrants who came to Denmark in the sixties and seventies as either young adults or children as well as young people who are born and bred in Denmark. This group was chosen for two reasons. First, having a history dating back to the 1960s, it is a well-established minority group in Denmark. Secondly, as Muslims, the group has increasingly experienced a signification as "strangers", and is regularly represented as a burden to the welfare state and a threat to nation. This has forced minority nationalism to formulate new and alternative perspectives on the nation that moves the debate away from what they find burdensome. In both projects the respondents were selected in order to obtain variation in terms of gender, age, education, employment and political belief.

The article is divided into three sections. In the first the analytical approach to nationalism is introduced. Inspired by the notion of banal nationalism the theoretical framework is developed focussing on how established nations in the western world reproduce the nation as a routine way of talking and acting in everyday life. I use the concept of banal nationalism as the ontological basis for the analysis of the everyday nationalism in Denmark. The theoretical framework addresses the nation as a narrative space constructed in a never ending everyday process of cultural signification.

The empirical part of the article is structured between the theoretical framework and the empirical material. In the analysis of majority and minority nationalism there is extensive use of extracts and narratives from the narrative material. The aim of the analysis is on the basis of the theoretical framework to illustrate how a new configuration of banal nationalism in Denmark is 
infiltrated by orientalist stereotypes but also how it is differentiated in its plurality. By analysing different perspectives on the nation from different narrative positions the analysis illustrate both shared narratives on the welfare state but also differences in the ongoing struggle over the right to the nation. The article is concluded with a discussion on the new configuration of banal nationalism in the Danish post-welfare state.

\section{Banal nationalism}

The approach to nationalism is inspired by Michael Billig's notion of banal nationalism (1995) and the "social poetics of the nationstate" of Herzfeld (1997). These terms describe how, in established nations like those in Europe, everyday practices reproduce national identities in ways so ordinary, so commonplace, that they escape attention altogether (Billig 1995, p. 8):

In so many little ways, the citizenry are daily reminded of their national place in a world of nations. However this reminding is so familiar, so continual, that it is consciously registered as reminding. The metonymic image of banal nationalism is not a flag which is being consciously waved with fervent passion: it is the flag hanging unnoticed on the public building.

Often nationalism in the eyes of western world is regarded as the property of the irrational other the peripheries, the revolutionaries, fascism or separatism. But as Michael Billig argues nationalism is a form of identity that not always consciously is "flagged" - it is based in the doxa (Bourdieu 1994) - the undisputed, pre-reflexive presuppositions of "the game" of everyday life.

Nationalism is produced in everyday practises as something ordinary. This may happen in speech acts, routinely and unconsciously using homeland-making phrases; small unnoticed words such as "we", "the" people, "this" country, "here", "society" and so forth or media announcements such as "the" weather, "home" news and "foreign" news and similar. Or it may occur through the use of material but symbolic items such as coins, banknotes or flags, hanging unnoticed from public buildings or used at birthday parties and other informal celebrations. When using these linguistic and material markers regularly, we are unmindfully reminded who we are and where we are. National identity becomes a routine way of talking and acting, a form of life. This daily and routine form of banal nationalism operates as a particularly strong social and 
political force right at the heart of western society, creating the continuous background for powerful political discourse. It equips us with an identity and ideological consciousness, encompassing and internalising us in a complex series of themes about "us" and "them", about the homeland and the world at large. It is instrumental in placing us in time and space, in a moral international world order, a larger world of nations. As Billig (1995, p. 109) notes,

The homeland is made both present and unnoticeable by being presented as the context. When the homeland-making phrases are used with regularity "we" are unmindfully reminded who we are and where we are. We are identified without even being mentioned. In this way national identity is a routine way of talking and listening; it is a form of life, which habitually closes the front door, and seals the borders.

Banal nationalism is 'the ideological habits which enable the established nations of the West to be reproduced' (Billig 1995, p. 6). It has in one way or another been passed over and has escaped out of sight. In this context "banal" should not be understood as something benign or innocent just because it apparently is a mechanism that ensures normality. Here banality is not synonymous with harmlessness (Arendt 1963). On the contrary, this banal nationalism reproduces powerful institutions which control large depositories of weapons. It ensures support for wars and repression and the continuation of an "imagined community", which can mobilize and prepare for the campaigns ahead. An example is the Danish involvement in the war in Iraq. Understanding of the connection between the banal and the more extreme originate from Hannah Arendt's study of the relationship between the banal and the evil in Eichmann in Jerusalem: A Report on the Banality of the Evil (1963) showing how banal routine and implicit obedience at its extreme can turn out a condition of possibility of radical evil. In this context it is of course a very different situation, but still there is connection between banal cultural racisms performed in gestures and speech and the advance of a radical populist right-wing party whose views have gradually been normalized and gained strong influence on the Danish agenda on "foreigners". In Denmark, the extreme not so much as elsewhere takes form of physical violence conducted by small groups or individuals. It is more a symbolic violence continuously shifting the limits of what it is possible to say about other groups of humans. While Billig's empirical analysis of banal nationalism is performed on the media, I build upon an investigation of how nationalism is also connected to everyday narrative practices. 
Nationalism is as argued by Smith (2010) not only a political ideology but also a politicized culture that can take many forms. Following Anderson (1991), who has formed an important basis for many recent theories of nationalism, the nation is an imagined political community imagined as both inherently limited and sovereign. It is imagined, he says, 'because the members of even the smallest nation will never know most of their fellow-members, meet them, or even hear of them, yet in the minds of each lives the image of their communion'. And it is limited because even the largest of them, encompassing perhaps a billion living human beings, has finite, if elastic boundaries, beyond which lie other nations' (Anderson 1991, p. 6). The imagined community is according to Anderson represented and mediated as an entity stretching and passing through time with its own past, future and destiny. This gives the imagined community its narrative character. As a space of belonging the nation is a territorial construction involving the production of bounded spaces in an international world of nation states. In the construction of nations and homelands, the central question arises: who belongs and who does not belong?

The nation is as a narrative space of belonging come as argued by Bhabha (1990) into being in an ongoing process of cultural signification, and as the representation of social life rather than the discipline of social policy. In this context the nation is also an "incomplete signification" that is created in the in between spaces through which the meaning of cultural and political authority are negotiated. It is exactly in such in between spaces that new critical and theoretical basis are developing says Bhabha (1990).

The thesis is that "in between spaces" and the narrative practices in everyday life constitute a central sphere inviting studies of the struggle over the imagined community and meaning. Inspired by Ricoeur (1984), who theorizes narratives in a way that on the one hand retains a connection between narrative and the world of practices and experiences, but on the other hand recognizes indefiniteness in this connection, one that is approached (but never remedied) through emplotment or the poetic of narrative (Simonsen 2004).

\section{Welfare nationalism}

To be Danish is for me that you have the freedom to create your life. You have some of the same ideals as in USA except that you also have a social safety net that picks you up if you can't fend for yourself. They don't have that in USA to which many compare themselves. Because in USA you are not picked up, you have to rise by yourself. And I would say that in 
Denmark you simply have so many possibilities to obtain a good life that if you can't, it's your own fault (Tariq, 37).

Tariq identifies himself as being Danish. He says he feels like a stranger when he goes to Pakistan, and he has not been there for 10 years. His Danishness is strongly connected to the set of rights obtained in Danish society: freedom rights and the rights related to public services, education, health and income distribution. Against this background we can characterize his Danishness as welfare Danishness (Koefoed 2006; Koefoed and Simonsen, 2007). It is a mode of national identity based on pride for the Danish welfare system, in Tariq's case in particular connected to an understanding of the welfare state as a "risk community": the welfare state is something that protects us against different kinds of risk to which we are exposed throughout our lives. The welfare state is an integrated part of everyday life and naturally related to the establishment of social security. Tariq expresses this form of Danishness by contrasting Denmark and the USA emphasizing the social safety-net in Denmark.

It is of enormous value that we all have the right to go to school, that we all have the right to go to hospital, and that none of us has to die of hunger (Kim, 42)

I mean these are some of the values we share in Denmark. It is freedom. Freedom to do what you want, education and welfare in general. That is very Danish. I feel that these kinds of value are also mine and something I contribute to and take part in (Tahira, 18)

I am very happy with the fact that we have social welfare in Denmark. That our society covers our daily needs. It is very important for every person, irrespective of whether he/she is Pakistanis, or Turkish or Yugoslav or Bosnian. I think that every human beings has a fundamental need for rights. Without society we can't make it. Because we also pay taxes so why should we not be giving the same opportunities? (Kaleem, 62)

Welfare is as a concept full of positive connotations, which in the myth of Danish civilisation symbolizes wealth, progress, community and a good life (Højrup 2003). In the international context, in contrast to other societies and nations, the Danish welfare state is perceived as 
something unique and valuable for the imagined community. As suggested by Kim in the extract, the Danish welfare system consists of a comprehensive set of rights related to public services, education, health and income distribution. In the extract, welfare is naturally tied to the national community.

As the narrative illustrates, it is "our" welfare, "we" have the right to public services (Kim) and it is 'values we share' as expressed by Tahira. In this sense it is perceived as a strong and familiar welfare community.

It is not just you and me. In reality it's our parents, isn't it? Who started building up the Danish welfare society? And that makes me happy. You can say that even if it looks like people don't talk so much to each other - that we don't visit each other so frequently - we are still all together in taking care of each other economically. In this perspective, you must understand that nobody is left out as such. That's the way it bloody well is! (Kim, 42)

The history of the Welfare State is a story beginning with the intimate family: 'it was our parents who created the Danish welfare society'. The welfare state ties the community together in a common history and destiny of this family; it equips the imagined community with meanings through discourses and practices of solidarity, equality and security.

In minority and majority nationalism the welfare state is organized as a meaningful category in everyday life in different ways. First, the welfare state is narrated as a labour community, emphasizing that it is something that we actively create and contribute to through hard work and high taxes, for instance as suggested by Kaleem. It is not a story of an abstract system or institutions, but a nationalism focusing on daily routines and practices related to a disciplined labour market. Secondly, it is articulated as a risk community: throughout our lives we are all exposed to different kinds of risk related to age, health, employment, education and housing. Here the welfare community is something that guarantees us a basic set of rights. The Danish welfare system is an integrated part of daily life and naturally related to the establishment of social security. Thirdly the welfare state has a central history and has to do with human beings fundamental needs for rights. In this sense welfare nationalism is a strong and shared narrative among minorities as well as majorities related to freedom, good life, solidarity and equality. 


\section{The Orientalization of welfare state}

In majority nationalism the welfare state connects to stories on how globalization (e.g. mobility and immigration) are posing a fundamental threat to the Danish welfare system. In all this, we are articulated as the majority and naturalized as the welfare state. Consequently, global and European mobility, the restructuring of public services and the re-scaling of political power are articulated as a loss, a dramatic change challenging the integrity of the nation. These challenges are articulated partly through expressions of anxiety and partly through an invisible glide towards Orientalist discourses, stereotypes and practices (Said 1985 and 2004).

They are only moving up here because they want us to support them, right? They are not coming because they want to help us. They are coming because they want something. It is our values. They want our benefits, right? That our older generation has created. They want their bloody part of the cake. (Karen, 52)

Our welfare society has deteriorated. In the hospitals we have waiting lists and people die like flies. And I don't understand how one can accept that as a doctor. [...] And I know that the person who is lying in there, if he does not get his operation tomorrow - if we wait another two weeks for space on the waiting list - then he will be dead. I saw it with my mother-in-law. She was lying there with a bad heart and needed help. And she was lying there for such a long time nearly getting really ill. She had her operation and that gave her ten good years. That was a good thing. But I mean ... it's exactly in such a case that one is saying: 'They should just have all the resources that they need'. Yes, but where would they get the money from? And in this case we notice that we have used too many resources on foreigners that we could have used in the Danish society instead. (Søren, 49)

What we experiences in Denmark and other Nordic countries is that crisis and challenges to the welfare state are articulated through an invisible glide towards Orientalist discourses and stereotypes. The progressive story of the Danish welfare community becomes the story of the threatening other. It is narratives that focus on the external other that is constructed as a mobile figure that not only intends to exploit the Danish Welfare State but also undermines it. In the above narratives the mobility of the Other represents a threat to the productive and imaginative 
welfare community. The external Other in the narrative is a mobile group of people attracted by "our values". The restructuring in the health sector is directly linked to the threatening mobility of immigrants and refugees. They become part of the same story. The internal Other becomes the explanation for any kind of difficulty or crisis in the service sector. The informant explains that the "welfare system has deteriorated". On the other hand the person says that "we have used too many resources on the foreigners'. In this narrative the internal Other is implicitly preventing the welfare system from saving lives. The narrative stages this as a conflict or a choice between us and them.

These narratives illustrate an everyday version of Orientalism - an imagination of cultural diversity building upon a binary dichotomy between us and them. It is a banal Orientalism that becomes clear in the phrase telling that it is 'our welfare' and 'they are coming because they want something'. This is what Billig (1995) is talking about when he draws our attention to the banality of the everyday construction of national identity through a routinized use of deictic markers that is, small unnoticed words gaining their meaning through the context in which they are used, such as we, us, here and this. These seemingly trivial words help to naturalize our affiliation to the national space and consequently to alienate the others. Notwithstanding our co-presence in the same territory, national identity is reserved to us and the others are constructed as strangers within "our" territory.

The narratives also illustrate an important aspect of orientalism and colonialism, as Bhabha (1983) argues the dependency on fixity in the construction of otherness. It is a fixity that implies repetition, rigidity and an unchanging order. The argument here is in line with Bhabha analysis of colonial discourses that the invisible glide towards orientalist discourse and stereotypes in majority nationalism, appeals to a cultural racism that naturalizes and essentializes cultural difference. According to that, immigrants are bound to cultures that are alien to the "Danish" one and resist integration into Danish society. Immigrants are a threat to Danish society, not only because they are supposed to "pollute" Danish culture, but also because they allegedly intend to "exploit" the Danish welfare system. This glide towards Orientalism is not what Billig (1995) characterizes as a "hot" nationalism. When it comes to the presence of extreme right-wing nationalist, racist and violent groups, Denmark is probably better off than many other countries in Scandinavia and Europe. What we experience instead is a "small" (and in a way more insidious) everyday racism, showing itself in a gradual slide in what it is socially acceptable to say and suggest - in political discourse and everyday talk - in relation to "foreign" Others. On the 
other hand, the new nationalism is not banal in the sense of unnoticed either; it is definitely articulated, penetrating into different spheres of everyday life.

Even though it is currently gaining prominence, the Orientalist perspective and discourse is, of course, not alone on the public scene. On the contrary, an "identity struggle" is performed over the definition of Danish identity and national space. The counter-perspective involved in this struggle may be designated a "humanist" discourse (Frello 2000) or a more cosmopolitan nationalism. According to that, Danish culture cannot be defined exclusively, and immigrants are not necessarily a burden on Danish society. They can just as well be an enrichment, as regards both culture and the economy. The argument is that banal nationalism is much more differentiated and blurred than they suggest (Koefoed 2006). Focusing on Orientalism alone means overlooking other significant voices, practices and perspectives on the nation.

\section{Minority nationalism}

The orientalization of the welfare state means that minorities are regularly produced as a burden and a thread to the imagined welfare community. But that does not imply that minorities disregard their Danishness. They approach the nation through narrative practices that opens up for new alternatives interpretations and inscriptions of meaning. In minority nationalism Danishness assumes a fluid form expressing a continuous identity work around possible affiliation to the imagined community. Basically they try to shift the focus from a burdensome debate on the nation, from which they have experienced an extensive degree of estrangement and exclusion, and to set forth new and different perspectives concerning what it means to be Danish. In the following I will present three different alternative interpretation of Danishness coming from minorities with Pakistani backgrounds.

\section{Participatory Danishness}

In narratives on participatory Danishness minorities imagining and equal community based, not on ethnic and cultural values but on social engagement and responsibility to the community. Listen for example, to this respondent:

To be Danish is for me to participate and be involved in society. That you are educated, and takes active part in the labour market, that you contribute to society. Pay taxes like everyone 
else. That you are engaged and try to better the conditions for others in the society. But today I am not so sure. What are Danish values? What does it mean to be Danish? I would certainly say that I usually justify it with: I was born and raised here. I know the language. I have an education and I work. I have been active in creating football clubs, cricket clubs, I am involved in public associations. I socialize with Danish friends on equal footing. I really can't see the difference between my good friend Morten or my good friend Søren or my good friend Muhammed because we are all equally Danish. (Hanif, 27)

In this narrative the nation gets meaning in relation to active participation and involvement in the society. It is a narrative practice that through tactic copes with the imagined other as being a passive (border) figure standing outside the community. Danishness in this narrative is not only about inclusion/exclusion it is about acting and doing. That you contribute in different context like the labor marked, through education or public associations. Hanif tells that he has been active in the local football club and cricket club and has taken initiatives in different public associations. When the nation is understood as participation the stereotyped categories lose signification. There is as Hanif rhetorical explains no reason to create difference between us and them. Thereby Danisheness as participation is told as a liberating and potential equal community. Not valorized on culture or ethnic background but on alternatively parameter like engagement, initiatives and responsibility. The narrative thereby creatively tries to moves the discussion away from what they find burdensome to perspective that are less cultural laden. Among the respondent participation and responsibility is a universal ethical claim something to do with being human but situated in a particular context it is about being active the place where you live your everyday life.

\section{Muslim Danishness}

Another perspective on the nation is the combination of belonging to a contested religious community and the nation, for instance being Muslim and Danish at the same time. In terms of religious community the narratives show great variety as regards the meaning of religion. For some it is primarily a platform for social engagement, others take a more pragmatic approach and talk about religion as a habit, and others again place it as their basic attitude to life:

I am a Muslim 24 hours a day (Ayoub 31) 
For me, Islam is the focal point in my life (Nasar, 32)

I am what I am because this is my country. This is the place where my home is, this is the place where I have my family. It is from here I have my childhood memories. So I can't go somewhere else, it would be illogical. But I have a background which is somewhat different from perhaps the majority of the people I live with. [...] On the one hand you can say that it is through Islam that I define myself. For me Islam is the glue. So I am Muslim but that does not make me less Danish. (Yasmeen, 26)

In this narrative Yasmeen tells that Islam is the glue that combines the different aspect of her identity. As part of that she generally as many other respondents emphasizes the moral and spiritual side of Islam more than the institutional rules and rituals. Focusing on the spiritual side of Islam primary makes it a personal matter concerning faith, inner purity and respect for other people. That is, primarily a moral-ethical position also expressed by Nasar and Ayoubs position when they talk about being 'Muslim 24 hours a day' or 'Islam as the focal point in life'. For Yasmeen Islam is the glue in the sense that it helps her building a bridge between the nation and her own background. For her Islam and Danishness is not in opposition. More Islam is not less Danishness. On the contrary in Yasmeens narratives they are a supplement to each other. For Yasmeen it is weaved together in her own live as a kind of hybrid identity that combines elements from different worlds and illustrate the multiple ways we can related to Danishness.

\section{Multicultural Danishness}

Multiculturalism is highly contested. It has manifold meanings situated in various localized, historical, academic and political context and conceptions. It can be considered as a floating signifier and it is as Fortier (2008, p. 3) points out more 'a horizon that fosters dreams or anxieties about the nations present and future' than a fact or a response to cultural diversification. Here the focus is on how the multicultural nation is imagined through new metaphors and practices in the search for a more inclusive and multifarious Danishness. 
I am also Danish if Denmark plays football, so of course I feel Danish. It is obvious. I am with Denmark when I watch football. If you take a look at the stands at football matches and so on, the fact is that it is a unifying, inclusive factor. Fan clubs, they are just interested in getting people in. Teakwondo clubs, all sorts of other sports, but it's about getting people included. But when it comes to debates over values and so on then they start to exclude people. We automatically do that. So there are many mechanisms at play. If you instead of values could start imagine Denmark as a great sports club. (Ikram, 31).

The respondents are generally occupied with finding new alternative ways of articulating nationhood. In the narrative material generally alternative practices and metaphors of a more multicultural imagined community is found in national events related to sport and music. Ikram tells later on in the interview that the taekwondo-milieu is the one that more than anything else has formed his view of the world. He started practising taekwondo in his teen and emphasizes the physical and colour blindness of the sport. 'The only colour that matter is the colour of your belt - in that sport neither skin colour or religion make a difference', he explains. In the above example Ikram in a similar way talks about football as being inclusive and unifying rather than exclusive. It can be a bridging force between national identity and the outside. Sport is multifaceted and at the same time national and global in scope. In sport it is more about letting people in than keeping them out. Thereby sport for Ikram has a lot of potential for a new and alternative way of imagine the nation. If we instead of the burdensome value debate could imagine Denmark as a one big sport club he suggest.

\section{Conclusion: nationalism in the Danish post-welfare state}

In comparing the different perspectives on the nation it becomes clear that there are similarities but also differences. I will argue for difference in two different ways. First, what I have tried to do in this article is to develop a possible understanding of what could be regarded as a new configuration of a differential banal nationalism in Denmark. The analysis illustrates that banal nationalism in everyday life has many voices and consequently should be treated as a plurality.

In the analysis it is clear that there is a shared and strong perspective among majorities as well as minorities on the nation as being a welfare community related to freedom, good life, solidarity and equality. This welfare nationalism is a shared narrative were the perspectives is on a 
basic set of rights related to public services, education, health and income distribution, solidarity and social security. In everyday life stories the imagined welfare community is not an abstract system but told as something we all contribute to through hard work (labour community) that defend the citizens in a risk community that protect "us" against different kinds of risk which we are exposed throughout our lives. Among minorities and majorities the welfare community is celebrated as a positive story uniting the nation in common expectation. This brings us secondly to another kind of difference between minorities and majorities.

Even though majorities and minorities agree and contribute actively to this welfare nationalism respectively it is also clear that there is a struggle over the right to the nation. Solidarity is for example one of the foundation stone of the welfare state, but what is unrecognized is the degree to which it has been based on a cultural concurrence of equality and likeness. In many cases, the unacknowledged presupposition of solidarity is a relatively homogeneous population (Molina 1997; Gullestad 2002). This is evident in the invisible glide in welfare nationalism towards orientalist discourses and stereotypes, where the internal and external other is seen as undermining "our" welfare state and exploiting resources created by "us". In this context Danish nationalism tied to the welfare state has placed a high degree of emphasis on solidarity understood in terms of cultural homogeneity. In majority nationalism the struggle over the right to the nation also uncover a negative affective cultural pessimism bounded to the feeling of ontological insecurity 'what will happen to our small country in this changing world of Europewide and global developments' with political affect based on economic chauvinism 'the wealth is ours and we do not want to share it with anybody' (Gingrich and Bank 2006, pp. 37-38). This narrative fantasy about that the other will steel something from us (Zizek 1993) is also based on a growth in national populism, right-wing nationalism, xenophobia and racism in Denmark that has penetrated into everyday life and in what is acceptable to say and suggest (see also Simonsen 2015, in this issue). At the same time orientalization of the Danish welfare state is not only a 'colonial present' (Gregory 2004) in a small scale it also has wider and more structural connections to the general transition in neoliberal governance from welfare state to security state and fragmented citizenship with for example different kinds of restrictions for immigrants and minorities. With the securitization of immigration we have a situation were as Lentin and Titley (2011, p. 172) argues if the neoliberal states function is to ensure citizens security rather than their welfare, it must protect the desirables from the undesirables by either locking them up or locking them out'. 
In minority nationalism there is also a claim of the right to the nation and that minorities should be recognised as equal members of the community. The difference is that minorities are forced to approach the nation through narrative practices that opens up for new interpretations and inscriptions of meaning. Basically they try to shift the focus from a burdensome debate on Danishness, from which they daily to an extensive degree are feeling estranged and excluded, to set forth new and alternative perspectives concerning what it means to be Danish. It is not a rejection of the nation or an attempt to dissolve it but rather a tactical way of coping with the dominating power (de Certeau 1984).

First, there is an attempt to move the debate from the dominating ethnic and cultural perspective to a political perspective on the nation. This is clear in narratives focussing on Danishness as participation. Participation links very much up with the part of welfare nationalism that in everyday life and practices talks about welfare as a labour community emphasizing that it is something "we" actively create and contribute to through hard work and high taxes. It is a dream about an imagined community not valorised on culture, colonial or ethnic background but on alternative parameters like engagement, initiatives and responsibility.

Secondly, minorities are actively looking for new metaphors and new ways of talking about the imagined community. In sport and music communities the respondents finds practices and languages that are not so infiltrated with fixed values and cultural judgement about who belongs and who does not belong. What the respondents are suggesting here is new ways of perceiving Danishness that combines the national with the global and multicultural way of living. In big national sports and music events we can both celebrate the nation and at the same time includes transnational citizens as iconic figure in the national fight and competition.

Thirdly minority nationalism is generally occupied with the nation as an open and more fluid and inclusive form. This differentiated understanding of national identity is not a fixed form of Danishness but about the complexity in living and identify with a multicultural and more open national identity. This comes close to a more transnational or cosmopolitan practice and identification with the nation as a competence in moving between cultures.

\section{Acknowledgements}

Thank you to the guest editors of this special issue and for fruitful discussions on Neoliberalism and Post-Welfare Nordic States in the workshop held at the University of British Columbia 
Centre for Social, Spatial, \& Economic Justice in Kelowna, Canada, in April of 2010. The research and the work of this article are kindly supported by the Danish Research Council.

\section{Lasse Koefoed}

Department of Environmental, Social and Spatial Change

Roskilde University

Postboks 260

4000 Roskilde

Denmark

E-mail:Lmartin@ruc.dk 


\section{References}

ANDERSON, B. (1991): Imagined Communities: Reflections on the Origin and Spread of Nationalism. Rev. edn. Verso, London.

ARENDT, H. (1963): Eichmann in Jerusalem: A Report of the Banality of Evil. Viking, New York.

BHABHA, H. K. (1983): 'The other question', Screen 24 (6): 18-36.

BHABHA, H. K. (1990): Nation and Narration. Routledge, London.

BILLIG, M. (1995): Banal Nationalism. Sage, London.

BRUN, E. and HERSH, J. (2008): 'The Danish disease: a political culture of Islamophobia', Montbly Review 60 (2): 11-22.

DE CERTEAU, M (1984): The Practice of Everyday Life. University of California Press, Berkeley, CA.

ERSBØLL, E. (2010: Eudo Cityzenship Observatory. Report on Denmark. Country Report, Denmark RSCAS/EUDO-CIT-CR 2010/13. Robert Shuman Centre for Advanced Studies, European University Institute, San Domenico di Fiesole, April.

FORTIER, A.-M. (2008): Multicultural Horizons: Diversity and the Limits of the Civil Nation. Routledge, London.

FRELLO, B (2000): Danskheden til forhandling. Kontur - Tidsskrift for Kulturstudier 1 (2): 30-39.

GELLNER, E. (1983: Nations and Nationalism. Cornell University Press, Ithaca, NY.

GINGRICH, A. and BANKS, M. (2006): Neo-nationalism in Europe and Beyond: Perspectives from Social Anthropology. Berghahn, New York.

GREGORY, D. (2004): The Colonial Present: Afghanistan, Palestine, Iraq. Blackwell, Oxford.

GULLESTAD, M. (2002): Det norske sett med nye oyne. Kritisk analyse av norsk innvandringsdebatt. Universitetsforlaget, Oslo.

HALDRUP, M., KOEFOED, L. and SIMONSEN, K. (2006): 'Practical orientalism - bodies, everyday life and the construction of otherness', Geografiska Annaler: Series B, Human Geography 88 (2): 173-184

HERTZFELD, M. (1997): Cultural Intimacy: Social Poetics in the Nation-State. Routledge, New York. 
HERVIK, P. (2012) 'Ending tolerance as a solution to incompatibility: the Danish "crisis of multiculturalism"”, European Journal of Cultural Studies 15 (2): 211-225.

HOBSBAWM, E. J. (1990): Nations and Nationalism since 1780: Programme, Myth, Reality. Cambridge University Press, Cambridge.

HØJRUP, T. (2003): Livsformer og velfardsstat ved en korsvej? Introduktion til et kulturteoretisk og kulturbistorisk bidrag. Museum Tusculanums Forlag, Copenhagen.

KOEFOED, L (2006): Glokale nationalismer. Globalisering, hverdagsliv og fortællinger om dansk identitet. PhD dissertation, Institut for geografi og internationale udviklingsstudier, Roskild Universitetscenter, Roskilde.

KOEFOED, L. and SIMONSEN, K. (2007): 'The price of goodness: everyday nationalist narratives in Denmark', Antipode 39 (2): 310-330.

KOEFOED, L. and SIMONSEN, K. (2010): Den fremmede', byen og nationen - om livet som etnisk minoritet. Roskilde Universitetsforlag, Frederiksberg.

LENTIN, A. and TITLEY, G. (2011): The Crisis of Multiculturalism: Racism in a Neoliberal Age. Zed, London.

MOLINA, I. (1997): Stadens rasifiering. Etnisk boendesegregation i folkhemmet. Geografiska regionstudier 32, Kulturgeografiska institutionen, Uppsala universitet, Uppsala.

RICOEUR, P. (1984): Time and Narrative. Volume I. University of Chicago Press, Chicago.

SAID, E. W. (1985): Orientalism. Penguin, London.

SAID, E. W. (2004): 'Orientalism once more', Development and Change 35 (5):869-879.

SIMONSEN, K. (2004): Spatiality, temporality and the construction of the city', in BæRENHOLDT, J. O. and SIMONSEN, K. (eds): Space Odysseys: Spatiality and Social Relations in the 21st Century. Ashgate, Aldershot, pp. 43-63.

SMITH, A. D. (2010): Nationalism. 2nd edn. Polity, Cambridge.

WREN, K. (2001): 'Cultural racism: something rotten in the state of Denmark?', Social and Cultural Geography 2 (2): 141-162.

ZIZEK, S. (1993): Tarrying with the Negative: Kant, Hegel, and the Critique of Ideology. Duke University Press, Durham, NC. 